\title{
THE MANAGEMENT OF INDONESIAN DOMESTIC WORKERS BASED ON GOVERNMENT PARTICIPATION IN CHINA
}

\author{
Elisabeth Tanti Pudiastuti ${ }^{1}$, Sukmo Hadi Nugroho ${ }^{2}$ \\ 1Sekolah Tinggi Manajemen STIMA IMMI Jakarta Indonesia \\ 2 Universitas Esa Unggul Jakarta Indonesia
}

\begin{abstract}
Indonesian domestic workers have been an interesting issue for several years. The existence of the workers, in one side, has played significant roles in generating income, reducing poverty, and generating economic development of the sending country. But in another side, they have also created complicated problems. The problems have frequently involved multiple stakeholders including governmental, non-governmental institution, and private sectors. Therefore, this study focuses on explaining Government participation in managing Indonesian domestic workers in China. China was chosen due to the number of the domestic workers. In order to explain the phenomenon, the researchers used qualitative research method. Consequently, the primary data was collected from interview. In addition, documentary analysis was also used in order to support the data. The study showed that there are at least some Government involved in managing Indonesian domestic workers such as National Agency of Placement and Protection of Indonesian Workers, Private Agencies in sending and receiving country, Ministry of Labor, and Ministry of Foreign Affairs. There are three processes of worker placement namely preplacement, while-placement, and post placement. The private agencies participated practically in almost all of the process including recruitment, providing education and training, and placement the workers. While, other Government participate in providing administrative process such as providing agreement, documents needed, legalizing private agencies, and collecting the data of the labors. However, administrative process was not run properly. It was because the workers and private sectors have to report their conducting activities. This condition gave impact to the lack of control to the activities. This was also exacerbated by the lack of participation from the workers. They don't have any information about the job and power to get protection. It was because of the existence of the law and lack of education. Therefore, knowledge about job, law, and involved Government was needed to increase participation and protection of the worker.
\end{abstract}

Keywords: Domestic Workers, Job Placement, Job Protection, Government Participation

\section{INTRODUCTION.}

\subsection{Background}

This study basically is an integral part of the research activities series that aims to review the application of good governance principle in Indonesian domestic workers management during the placement in the destination country. Especially, it is related to the application of the Government participation principle in the Indonesian domestic workers management during the process or placement stages pre-placement, while-placement and post-placement in the destination country. The destination country here primarily is China which until now has become the main destination for Indonesian domestic workers.

As stated in the data of National Agency of Placement and Protection of Indonesian Overseas Workers in 2019 that China becomes the highest placement country among the other destination ones with 87.616 Indonesian workers. It is the same as 37,4 percent from the total of Indonesian overseas workers placement that is 234.451 people in 2019. The globalization that flows stronger has opened job opportunities for women, including the women from developing countries in order to migrate to another country. ILO (2004), [24] states that from 86 million migrant workers around the world, there is a great number of women workers that reaches more than the half of all migrant workers around the world. This also happens in Indonesia in the placement of Indonesian overseas workers which is dominated by women, that $62 \%$ of Indonesian overseas workers are women in 2019.

In line with the review of this research, the number of Indonesian overseas workers in China in 2018 was 97.635 people; they were 58.297 men and 39.338 women. The majority of migrant workers work in a job sector that is categorized as " $3-D$ " (dirty, dangerous and difficult). As a result, the migrants become very vulnerable to any kind of discrimination, violence, humiliation, and even serious violation to human rights (ILO, 2004), [24]. The condition in 2019 reveals that the majority of Indonesian overseas workers in trouble are dominated by those who work as domestic workers or domestic assistants. As reflected in the phenomenon during January-August 2019 period, Indonesian overseas workers in trouble that were accommodated in the Republic of 
Indonesia Embassy Shelter in Peking, China was $93 \%$ of Indonesian domestic workers, and the rest $7 \%$ was Indonesian male overseas workers. Besides, the Indonesian domestic workers who are in trouble are those who went abroad through informal agencies.

One of the violence forms that has become main attention from all circles until now is violence towards Indonesian overseas workers. This does not fit the mandate of the Constitution number 39, 2004 that guarantee and protect the Indonesian overseas workers. In fact, Indonesian overseas workers, especially domestic workers have not been protected properly either on pre-placement, whileplacement or post-placement stage. Many cases that afflict Indonesian overseas workers are like an endless tangled thread, including violent acts, sexual harassment, unpaid salary, working hours and break time violation that are not consistent with the agreement that has been settled together, and other acts that violate human rights [2].

In line with the basic principle that the first and the best protection for Indonesian overseas workers comes from the workers themselves, so that the participation problems in managing Indonesian overseas workers pre-placement, while-placement and post-placement in the destination country becomes very relevant and urgent to be strengthened. Government' roles, either from government, private sectors, or civil society needs to be improved in order to give protection on the preplacement, while-placement, and post-placement stages, especially related to the preventive protection given to Indonesian overseas workers during the pre-placement stage. It is caused by the problems of Indonesian overseas workers that appear $70 \%$ during this pre-placement stage. Indonesian overseas workers candidates have not been able to protect themselves. It can be seen from the numbers of the candidates who are tempted by the informal agencies and the document forgery. In line with the background of the study, this research discusses the problems that are related to how the Government' participation in managing Indonesian overseas workers [4]. The research about Government' participation is important since Indonesian overseas workers management involve multi Government that are related to each other with their roles and functions that have been set.

\section{MATERIAL AND METHODS}

\subsection{Good Governance and Participation}

The concept of governance can be easily defined as managing by the network, management that is based on the participation and synergy from all the Government. They are the Government that come from government, private sectors, society, and the targeted citizens themselves. And, the best practice of governance is well known as good governance. World Bank (2009) [25] defines governance as the way state power is used in managing economic and social resources for development of society. Similar definition is stated by UNDP (2006) [26] that governance as the exercise of political, economy, and administrative authority to manage a nation's affair at all levels [8].

More specifically, in the concept of good governance, there are three legs and three domains [1]. The three main legs here are political governance, economic governance and administrative governance. Political governance refers more to the process of policy making. Economic governance refers to the process of decision making in economic field that imply on the problems of equity, poverty reduction and life quality improvement. And, administrative governance refers more to the system of policy implementation.

The three main domains include the components of the state, private sectors, and civil society [3]. These three governmental components need to relate harmonically in order to reach a synergy. A harmonic relationship and synergy among these three governmental components can be built if those three have the same levels and roles and also be able to control each other effectively.

Moreover, World Bank (2009), [25] states that good governance can be defined as a performance of a solid and responsible development management that is in line with the democracy principle and efficient market, avoidance of wrong allocation of investment funds, prevention of politically and administratively corruption, budget discipline implementation, and legal and political framework creation [10].

Participation is an important component in governance, especially for developing independence and empowerment process. [6] confirms that participation is a potential strategy in developing economy, social, and culture transformation. This process eventually will be able to create developmental governance that is centered on the society. [23], further explains that there are seven participation typology characteristics, they are:

a. Passive or manipulative participation; it is a form of the weakest participation. The characteristics are the society accepts the notice on what is going on and what has happened. One side announcement by the implementers does not pay attention on the society's response as the target.

b. Informative participation; the society answers the questions for the projects, but they do not involve and affect the decision process.

c. Consultative participation; the society participates by consulting, and the outsiders listen and analyze the problems and the solutions. 
d. Incentive participation; the society gives sacrifices and services in order to gain incentive rewards in a form of wage, even though they are not involved in the process of learning and experiments.

e. Functional participation; the society forms a group as the part of the project, after main decisions have been agreed.

f. Interactive participation; the society plays a role in the analysis process in planning the activities and forming or strengthening the organization. This pattern tends to involve the interdisciplinary method that seeks variety of perspectives in the structured and systematical learning process.

g. Independent participation (selfmobilization); the society takes their own initiatives freely in order to change the system or values they respect.

\section{RESEARCH METHODOLOGY}

The type of research that is used in this research is the type of descriptive research with qualitative approach. The focus of this research is the Government' participation government, private sectors, and society in managing Indonesian overseas workers. Moreover, the location of this research is in Indonesia and China with the research site is National Agency of Placement and Protection of Indonesian Overseas Workers, Republic of Indonesia Embassy in China, and Republic of Indonesia Embassy Shelter China. In collecting data, the researchers used observation technique, interviews, and documentation. In the data collection, the researchers used qualitative data analysis that is stated by [5] that starts from data collection, data reduction, data display, and data conclusion drawing/verification.

\section{RESULT AND DISCUSSION}

The management of Indonesian domestic workers basically consists of the process of placement and protection. In Indonesia, the process of the placement and protection is regulated in the Constitution Number 39, 2004 about Placement and Protection of Indonesian Overseas Workers. However, this paper would review more about the placement of Indonesian domestic workers. It is caused by the placement process is the biggest portion in the activities of managing Indonesian overseas workers [7]. Besides, Government that are involved in the placement process also vary from the government and private sectors. The placement process is also the first gate to enter in the process of Indonesian overseas workers management. It can be concluded that, if we want to solve the Indonesian overseas workers' problems, the main requirement that needs to be fulfilled is to identify the placement process [9].

Basically, according to the Constitution number 39, 2004, placement process consists of three main stages, they are: 1) Pre-Placement 2) While-Placement, and 3) Post-Placement. These placement stages involve several main factors, they are; China agencies, Representatives of Republic of Indonesian in China, National Agency of Placement and Protection of Indonesian Overseas Workers, and agencies in Indonesia. Figure 1 describes clearly about the placement process that should be conducted according to the Constitution number 39 , 2004.

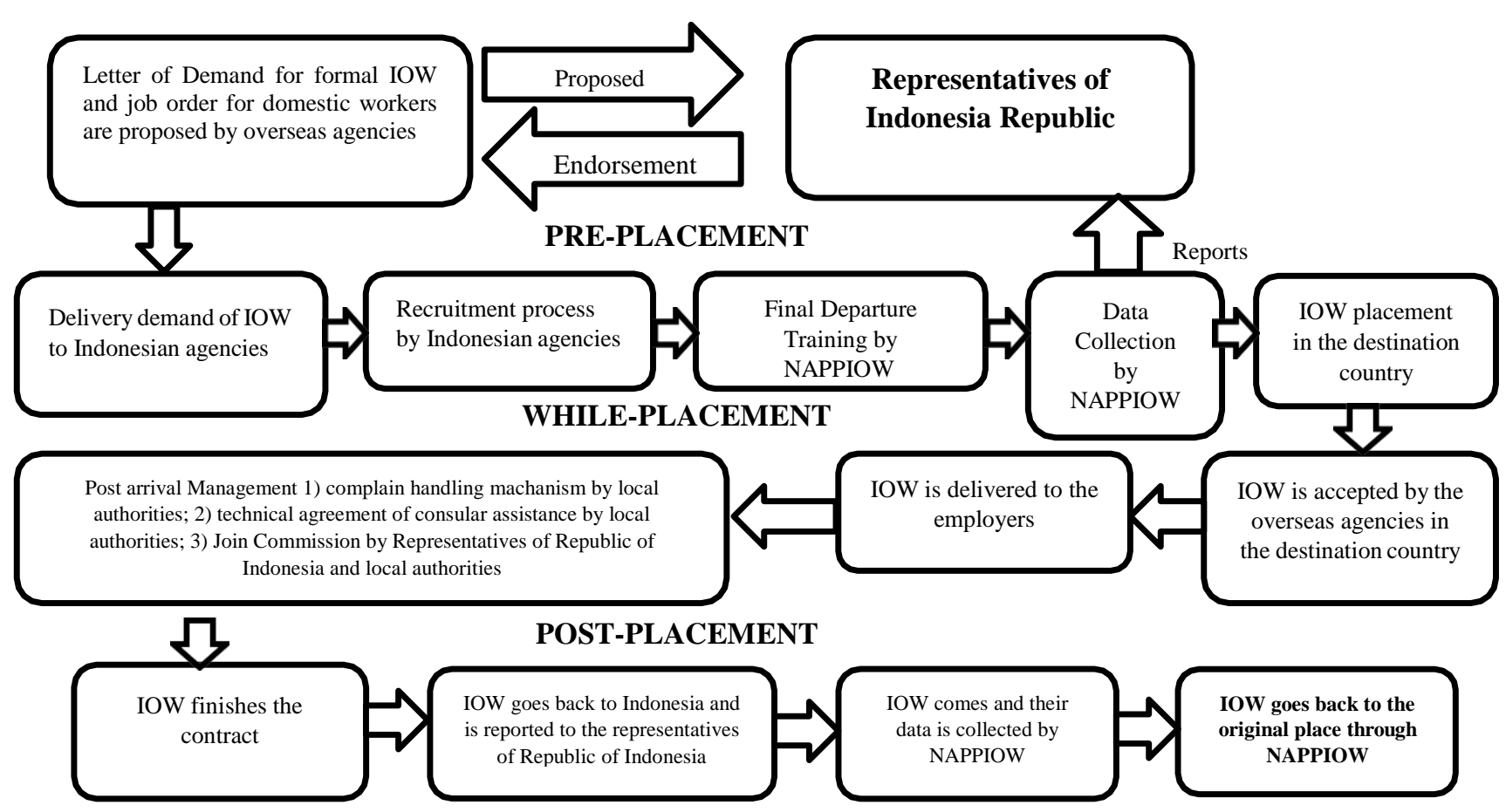

Figure 1. Placement Process of Indonesian Overseas Workers 
That figure shows that the representatives of Republic of Indonesia in China play a role to give legality toward China agencies to recruit Indonesian overseas workers through publishing job order for the domestic workers. This activity is conducted by the representatives of Indonesian Ministry of Foreign Affairs in China. Job order will be made as groundwork of China agencies to demand a number of workers that will be placed as domestic workers from Indonesian agencies. Even though the Constitution number 39, 2004 has explained that overseas agencies only propose job order to recruit the domestic workers candidates, however, in fact they do publish not only job order, but also letter of demand that can be used to recruit Indonesian overseas workers who will work in formal sectors. It is often misused by both China and Indonesian agencies. Oftentimes, Indonesian overseas workers are recruited by Indonesian agencies to be placed in formal sectors. However, in fact, after they arrive in the destination country and are accepted by China agencies, they are placed as domestic workers [11]. Generally, Indonesian overseas workers candidates do not have proper education, so that they do not know the placement process or the contract agreement. It is worsened by the government's role on pre-placement stage.

According to the Constitution number 39 , 2004, the government through Indonesian agencies only gives Final Departure Training and collecting the Indonesian overseas workers' data. The Final Departure Training given should be related to the knowledge of regulation, protection agencies in China, and information about the job of Indonesian overseas workers candidates. However, in the real condition, it shows that most of the candidates do not receive that kind of training. Indonesian agencies only collect their data, especially related to the administrative requirements to move and work in China. Therefore, most of the Indonesian overseas workers do not know about the governmental protection agencies in China, such as Republic of Indonesia Embassy, NGO, and agencies in China that are responsible for their existence. Indonesian agencies then report to the representatives of Republic of Indonesia in China, especially to the representatives of Indonesian Ministry of Manpower [13]. Next, placement process of Indonesian domestic workers in China is submitted to the Indonesian and China agencies in order to reach the employer.

When Indonesian overseas workers arrive in China, Indonesian government's role becomes weak, especially to control and give protection towards them. Most of the processes, such as PostArrival Management and technical agreement of consular assistance are conducted by China government. Indonesian government has only a role through join Commission. Working location of the domestic workers that are mostly inside a house, and they become very dependent on the employer weakens the control that can be done by the government. Indonesian overseas workers are required to be actively reporting themselves through Indonesian Embassy [15]. However, many of them do not know about Indonesian Embassy. It happens because Final Departure Training is only done to process their data and document collection and oftentimes, visa extension arrangement is conducted by the employers. The weak government's role in giving protection and conducting control towards Indonesian domestic workers becomes the main cause of the amount of violation towards them [17].

Besides, the figure above also shows that government's control toward the agencies both in Indonesia and China are very weak. Every Indonesian overseas worker candidate that is recruited by Indonesian agencies must be reported to National Agency of Placement and Protection of Indonesian Overseas Workers [19]. Therefore, Indonesian agencies are required to be actively reporting every Indonesian overseas workers candidate they recruit. Meanwhile, there is not any significant reward or punishment to Indonesian agencies that report every candidate they recruit. It causes a lot of violation done by Indonesian agencies. They often use brokers to do the recruitment. Their purpose using the brokers is to gain as many workers and as much profit as possible. It increases the number of deviation in the recruitment process, such as the incompatibility working contract with the job [12].

Moreover, for the post-placement or postIndonesian overseas workers, when they arrive in Indonesia, they become the responsibility of National Agency of Placement and Protection of Indonesian Overseas Workers. Its effort is by giving knowledge training to the ex-Indonesian overseas workers in order to increase their independence so they will not go back to the destination country [14]. The knowledge training is directed to form a new or creative business. Forming a new or creative business can done when they are still in another country by giving their salary to their family in Indonesia, so when they finish their contract and go back to Indonesia, their business would have been formed and conducted well

\section{CONCLUSION}

Based on the result above, it can be concluded that Indonesia places Indonesian domestic workers as the object in managing Indonesian overseas domestic workers. It happens in all placement process, either in pre-placement, while-placement, or post-placement. In preplacement stage, it only involves the government and private sectors. The government's role is played by consulate affairs in giving legality towards China 
agencies to draw workers from Indonesia, and also by National Agency of Placement and Protection of Indonesian Overseas Workers in giving final placement training and data collecting. Meanwhile, the private sectors' roles are played by China agencies as the connector of Indonesian domestic workers candidates with the employers; and Indonesian agencies as the recruiters and the distributors of the workers. In this phase, there are several problems, such as:

a. The role of National Agency of Placement and Protection of Indonesian Overseas Workers is not run optimally. This agency, according to the constitution number 39, 2004, becomes the last door for the Indonesian domestic workers who will work in China. Therefore, it plays very important role in guaranteeing the sustainability of Indonesian overseas workers in China by providing trainings and data collecting. However, in fact, that function is not run well because the trainings provided tend to be administratively without giving proper knowledge to the candidates about their jobs and other mechanisms about placement and protection. It causes a lot of Indonesian domestic workers that are in trouble do not have access toward the protection efforts. Besides, the low quality of their education causes their weak motivation and creativity in the efforts of gaining information and protection.

b. National Agency of Placement and Protection of Indonesian Overseas Workers is more passive in conducting their action. As explained before, reporting activities are conducted individually by Indonesian agencies. It means that National Agency of Placement and Protection of Indonesian Overseas Workers is very passive in conducting controls toward all activities of Indonesian agencies.

c. The controlling actions toward Indonesian agencies in the workers recruitment and distribution process are weak. The reporting process has to be done by every Indonesian agency to National Agency of Placement and Protection of Indonesian Overseas Workers to be next reported to the Representatives of Republic of Indonesia in China. However, there is not any clear reward for Indonesian agencies that report to National Agency of Placement and Protection of Indonesian Overseas Workers or forceful punishment for those that don't. Because of its passive action and unclear reward and punishment, a lot of Indonesian agencies that are not serious in making the reports. It causes controls toward all actions of Indonesian agencies become very weak [21]. Those weak controlling actions make Indonesian agencies become very free in conducting their actions in order to gain as much profit as possible and to accelerate their jobs. Furthermore, Indonesian agencies also have several brokers that recruit people as many as possible, especially those who have low quality of education.
Eventually, all pre-placement until while-placement stages are done by Indonesian agencies themselves.

In the while-placement process, it only involves China and Indonesian agencies, and the employers. In this stage, Indonesian domestic workers seem like some items that are traded from one hand to another. It is worsened by the weak controlling actions that are done by the Representatives of Republic of Indonesia government in China. Indonesian government only has a few roles in Join Commission. While in the post-placement process, it is National Agency of Placement and Protection of Indonesian Overseas Workers only that plays a role to manage. Indonesian agencies as the distributor of Indonesian domestic workers should take a part in guaranteeing the sustainability of the workers and give evaluation to the agencies in China [22].

Based on the description above, it can be concluded that in fact the concept of good governance in managing Indonesian overseas workers is not conducted properly. There is not any harmonic interaction, especially between the government and the private sectors. It is caused by the passive actions of the government that only focuses on the administrative matters. It is also caused by the private sectors that want to gain as much profit as possible [16]. It seems like all placement processes are done by the agencies only without any government involved. The majority of the society assumes that the government only plays a role in collecting their data. Therefore, the government's role has not been perceived by Indonesian domestic workers.

Furthermore, it is also worsened by the poor coordination among the governmental agencies. It is caused by the interaction that tends to be reporting only. There is not any collaboration effort that is formed in real actions in managing Indonesian domestic workers. In fact, each agency conducts the effort to improve its own domestic workers' welfare so that it is sometimes overlapped. It causes to weaken the communication among the agencies that it eventually can trigger some misunderstandings that later can cause several conflicts [18]. As an example in the while-placement process, National Agency of Placement and Protection of Indonesian Overseas Workers plays a role in providing training and collecting their data, while the Representatives of Republic of Indonesia in the destination country plays a role to conduct protection. Meanwhile, Indonesian domestic workers are very vulnerable to various problems. If there is not any good communication among the governmental agencies, this condition would be a boomerang that can trigger conflicts among those agencies.

Moreover, domestic workers themselves are not involved in the actions of managing Indonesian overseas workers. Whereas, in the concept of good governance, there are three main components in the 
management, they are the Government, Private Sectors, and the Society Indonesian overseas workers [20]. Those three governmental components need to have a harmonic relationship in order to reach synergy. A harmonic relationship and synergy among those three governmental components will be achieved if those three have the same levels and roles and be able to conduct effective controlling actions toward each other. In this case of Indonesian domestic workers in China, the society is only the object. Besides, there is not any harmonic relationship between the government and the private sectors in managing Indonesian overseas workers [23]. Each actor runs their own actions in order to reach their own organization's goals.

The study showed that there are at least some Government involved in managing Indonesian domestic workers such as National Agency of Placement and Protection of Indonesia Workers, Private Agencies in sending and receiving countries, Ministry of Labor, and Ministry of Foreign Affairs. There are three processes of workers' placement namely pre-placement, while-placement, and postplacement. The private agencies participated practically in almost all of the processes including recruitment, providing education and training, and workers placement. While, another stakeholder participates in providing administrative process such as providing agreement, documents needed, legalizing private agencies, and data collection of the labors. However, administrative process was not run properly. It was because the workers and the private agencies have to report their activities. This condition gave impact to the lack of control to the activities. This was also exacerbated by the lack of participation from the workers. They don't have any information about the job and power to get protection. It was because of the existence of the law and lack of education. Therefore, knowledge about job, law, and involved Government was needed to increase participation and protection of the workers.

\section{ACKNOWLEDGEMENT}

The authors greatly acknowledge the support from Sekolah Tinggi Manajemen STIMA IMMI Jakarta and Universitas Esa Unggul Jakarta Indonesia for providing the necessary resources to carry out this research work. The authors are also grateful to the anonymous reviewers and journal editorial board for their many insightful comments, which have significantly improved this article.

\section{REFERENCES}

Ahmadi, \& Herdiawan, D. (2019). The application of CBA and SUG model for improving the quality of Indonesian navy human resources. International Journal of Recent Technology and Engineering, 8 (3), 393-
399.

https://doi.org/10.35940/ijrte.C4190.098319

Bandono, A. D. I., Suharyo, O. S., \& Riono. (2019). Applied fuzzy and NASA tlx method to measure of the mental workload. Journal of Theoretical and Applied Information Technology, 97(2), 476-489

Badan Nasional Penempatan dan Perlindungan Tenaga Kerja Indonesia (2017). Laporan Kinerja BNP2TKI Tahun 2016

(Accountability report of NAPPIOW 2016). Jakarta: BNP2TKI.

Hariri, A., Mubarok, A., Wibowo, U. L. N., \& Fathafirza, M. A. (2020). STUDY ON SATISFACTION LEVEL IMPLEMENTATION OF E-LEARNING AS SUPPORTING MEDIA LEARNING THE ACADEMY AVIATOR INDONESIA BANYUWANGI. SOSIOEDUKASI: JURNAL ILMIAH ILMU PENDIDIKAN DAN SOSIAL, 9(1), 76-80.

Herdiawan, D., \& Ahmadi. (2019). Development strategy of national food sovereignty to encounter radicalism threat. International Journal of Innovative Technology and Exploring Engineering, 8(11), 544-553.

Haricahyo, D., Wibowo, U. L. N., Mubarok, A., \& Martono, H. E. (2020). FAKTOR-FAKTOR YANG MEMPENGARUHI SISWA SMK DALAM PEMILIHAN JURUSAN DI SMK MUHAMMADIYAH 9 GAMBIRAN KABUPATEN BANYUWANGI. SOSIOEDUKASI: JURNAL ILMIAH ILMU PENDIDIKAN DAN SOSIAL, 9(3), 227-232.

Hikmat, H. (2004). Strategi Pemberdayaan Masyarakat (Strategy of Social Empowerment). Bandung: Humaniora.

Kantor Perburuhan Antara bangsa (Internasional Labour Organization, ILO) (2004). Mencegah diskriminasi, exploitasi, perlakuan sewenang-wenang terhadap pekerja migran wanita (Preventing discrimination, exploitation, abuse of women migrant workers), . Jakarta: Press.

LAN \& BPKP. (2000). Akuntabilitas dan Good Governance (accountability and good governance). Jakarta: Modul AKIP.

Mardiasmo (2002). Otonomi dan manajemen keuangan daerah (Local autonomy and financial management). Yogyakarta: PT Andi. 
Martono, H. E., Putra, R. H., Mubarok, A., \& Wibowo, U. L. N. (2020). PEMANFAATAN PERPUSTAKAAN SEKOLAH DAN ATMOSFER AKADEMIK SMK PGRI ROGOJAMPI. SOSIOEDUKASI: JURNAL ILMIAH ILMU PENDIDIKAN DAN SOSIAL, 9(3), 252-259.

Miles, H. S. (2014). Qualitatif Data Analysis (Qualitative Data Analysis). United State of America: Sage Publication.

Ministry of Manpower Decree Number 22, Year 2014 about Implementation of Placement and Protection of Indonesian Overseas Workers.

Nugroho, S. H., Madhakomala, R., \& Gunawan, K. (2019). The system dynamic model for policy evaluation of navy personnel on the state-duty aspect. International Journal of Scientific and Technology Research, 8(12), 228-236.

Nugroho, S. H., Madhakomala, R., \& Gunawan, K. (2019). Analysis and scenario of navy performance allowance policy using system dynamic model. International Journal of Scientific and Technology Research, 8(12), 1140-1147.

Nugroho, S. H., Sukandari, B., Suharyo, O. S., \& Bandono, A. (2020). The application of Nasa-TIx methods to the analysis of Mtf navy personnel allocation. International Journal of Scientific and Technology Research, 9(3), 6172-6179.

Prasetyo Iswahyudi, Dewie Tri Wijayati, Soedjarwo Soedjarwo, Sugi Hartono, (2020) The Effects of Inner and Outer Green Supply Chain and Eco-Drawing on the Environmental Sustainability in Indonesia, International Journal of Supply Chain Management, Vol 9 no 2.

Prasetyo Iswahyudi, Genny Luhung Prasojo, AHMAD HARIRI, Ridho Rinaldi, (2020) THE EFFECT OF KNOWLEDGE SHARING ON THE RELATIONSHIP BETWEEN INDIVIDUAL COMPETENCIES AND CREATIVITY FOR CADET AT THE INDONESIAN PILOT ACADEMY, ICOPE December 2020.

Prasetyo Iswahyudi, Mubarok, A., Arif, R., \& Wibowo, U. L. N. (2020). THE EFFECT OF SERVICE QUALITY, AND CORPORATE IMAGE ON LEARNING SATISFACTION AND STUDY LOYALTY AND ITS IMPACT ON MOUTH WORDS IN ALL GROUP MINISTRY OF RELATIONS AVIATION
VOCATIONAL COLLEGES.

SOSIOEDUKASI: JURNAL ILMIAH ILMU PENDIDIKAN DAN SOSIAL, 9(1), 76-80.

Reza, H. K., \& Nugroho, S. H. (2020). Relationship analysis of motivation and customer satisfaction on services quality aspect for online transportation. International Journal of Scientific and Technology Research, 9(4), 1101-1108

Regulation of Head of National Agency of Placement and Protection of Indonesian Overseas Workers Number 4 Year 2017 about Empowerment of Indonesian Overseas Workers, Post-Indonesian Overseas Workers, and Their Family.

Setiadji, A., Marsetio, \& Ahmadi. (2019). The assessment of strategic planning and strategic change management to improve organizational performance. International Journal of Advanced Science and Technology, 29(5), 682-698.

Sudjoko, R. I., \& Iswahyudi, P. (2020). Speed Control of Permanent Magnet Synchronous Motor Using Universal Bridge and PID Controller. In Proceedings of the 6th International Conference and Exhibition on Sustainable Energy and Advanced Materials (pp. 405416). Springer, Singapore.

Sugiyono. (2012). Quantitative and Qualitative Research Methods And R \& D. Alfabeta Bandung.

Suharjo, B., Suharyo, O. S., \& Bandono, A. (2019). Failure mode effect and criticality analysis (FMECA) for determination time interval replacement of critical components in warships radar. Journal of Theoretical and Applied Information Technology, 97(10), 2861-2870. https://doi.org/10.5281/zenodo.3256535.

Suharjo, B. (2019). Using System Dynamics to Analyze the Leadership Style on Motivation and Soldier's Performance. In E3S Web of Conferences (Vol. 125). EDP Sciences. https://doi.org/10.1051/e3sconf/201912522 002.

Sulung, S. D., Mubarok, A., Arif, R., \& Rusdiansyah, A. (2020). ACTIVE LEARNING MODELS INCREASE CADET ACADEMIC VALUE. SOSIOEDUKASI: JURNAL ILMIAH ILMU PENDIDIKAN DAN SOSIAL, 9(1), 55-61.

Sumantri, S. H., Bastari, A., \& Sri Suharyo, O. (2019). The assessment of naval base sustainability using a dynamic system thinking approach. 
International Journal of Scientific and Technology Research, 8(11), 388-394.

Susilo, A. K., Putra, I. N., Ahmadi, \& Suharyo, O. S. (2020). Analysis of national maritime security strategy as an effect of regional development using SWOT, fuzzy multicriteria decision making (FMCDM), and borda. International Journal of Operations and Quantitative Management, 25(3), 153174.

Syahyuti (2006). Konsep Penting dalam Pembangunan Pedesaan dan Pertanian (Main concept Village and Agriculture Development). Jakarta:Gramedia.

The World Bank (2009). Building Blocks for Good Forest Outcomes: An Analytical Framework for Governance Reform, ESW prepared by the Forest Team, Agriculture and Rural Development Departemen. The World Bank : Washington D.C.

UNDP. (2006). UNDP and Governance: Experieces and Lesson Learned. New York: MDG Division- UNDP. 